Jurnal Inkofar * Volume 1 No. 1, Juli 2017 * ISSN: 2615-3645 (Print) / 2581-2920 (Online)

Tersedia secara online di: http://www.politeknikmeta.ac.id/meta/ojs/

\title{
STUDI PERBANDINGAN ALGORITMA - ALGORITMA STEMMING UNTUK DOKUMEN TEKS BAHASA INDONESIA
}

\author{
Manase Sahat H Simarangkir \\ Program Studi Teknik Komputer, Politeknik META Industri Cikarang \\ Cikarang TechnoPark Building Jalan Inti 1 Blok C1 No.7 Lippo Cikarang Bekasi \\ Email : manasemalo@politeknikmeta.ac.id
}

\begin{abstract}
ABSTRAK
Stemming merupakan proses untuk memetakan berbagai variasi morfologikal dari kata menjadi bentuk dasar yang sama, dengan menghilangkan semua imbuhan baik yang terdiri dari awalan, sisipan, akhiran dan kombinasi dari awalan dan akhiran pada kata berimbuhan. Pada penelitian ini digunakan dua algoritma stemming berbasis kamus dan dua algoritma stemming menggunakan aturan imbuhan. Pengujian dilakukan menggunakan 100 dokumen teks Bahasa Indonesia yang sudah ditentukan sebelumnya. Hasil pengujian yang dilakukan menunjukkan bahwa waktu proses stemming yang paling cepat terdapat pada algoritma Vega, akurasi yang paling tinggi terdapat pada algoritma Nazief dan Adriani, overstemming yang paling sedikit terdapat pada algoritma Nazief dan Adriani karena nilainya lebih rendah, understemming yang paling sedikit terdapat pada algoritma Nazief dan Adriani karena nilainya lebih rendah. Dari pengujian yang dilakukan menunjukkan bahwa algoritma yang paling baik terdapat pada algoritma Nazief dan Adriani.
\end{abstract}

Kata Kunci: stemming, dictionary based, purely rule based, overstemming dan understemming.

\section{PENDAHULUAN}

Pencarian informasi berupa dokumen teks atau yang dikenal dengan istilah Information Retrieval (IR) merupakan proses pemisahan dokumen-dokumen yang dianggap relevan dari sekumpulan dokumen yang tersedia. Bertambahnya jumlah dokumen teks yang dapat diakses di internet diikuti dengan meningkatnya kebutuhan pengguna akan perangkat pencarian informasi yang efektif dan efisien (Agusta, 2009). Efektif berarti user mendapatkan dokumen yang relevan dengan query yang diinputkan, efisien berarti waktu pencarian yang sesingkat-singkatnya.

Stemming merupakan suatu proses untuk menemukan kata dasar dari sebuah kata. Stemming merupakan proses yang memetakan bentuk varian kata menjadi kata dasarnya (Tala, 2004). Dengan menghilangkan semua imbuhan (affixes) baik yang terdiri dari awalan (prefixes), sisipan (infixes), akhiran (suffixes) dan confixes ( kombinasi dari awalan dan akhiran ) pada kata turunan. Untuk stemming dalam bahasa Indonesia, terdapat dua jenis metode stemming yang sudah ada, yaitu algoritma stemming yang berbasis kamus (dictionary based) dan algoritma stemming yang berbasis non-kamus (purely rule based).Dalam stemming Bahasa Indonesia, digunakan beberapa teknik pendekatan seperti stemming yang dilakukan oleh stemmer Tala, Porter, Arifin dan Setiono, Nazief dan Adriani, Vega. Sebenarnya hampir tidak ada persetujuan umum mengenai keefektifan dari teknik-teknik pendekatan tersebut. Masalah lain dari stemming adalah ketergantungan dari beberapa teknik stemming tersebut pada kamus yang luas (comprehensive dictionary).

\section{TINJAUAN PUSTAKA}

\subsection{Imbuhan Bahasa Indonesia}

Bahasa Indonesia adalah bahasa yang memiliki morfologi yang berbeda dengan bahasa lainnya. Bahasa Indonesia memiliki imbuhan-imbuhan yang beraneka ragam. Sering kali sebuah kata dasar atau bentuk dasar perlu diberi imbuhan untuk dapat digunakan dalam pertuturan (Chaer A, 2011). Imbuhan ini dapat mengubah makna, jenis dan fungsi sebuah kata dasar atau bentuk dasar menjadi kata lain yang fungsinya berbeda dengan kata dasar atau bentuk dasarnya. Imbuhan mana yang harus digunakan tergantung pada keperluan penggunanya di dalam pertuturan. Imbuhan yang ada dalam bahasa indonesia adalah : 
Jurnal Inkofar * Volume 1 No. 1, Juli 2017 * ISSN: 2615-3645 (Print) / 2581-2920 (Online)

Tersedia secara online di: http://www.politeknikmeta.ac.id/meta/ojs/

a. Partikel (Particle) -lah, -kah, -pun.

Contoh : pergi + lah $=$ pergilah, buku $+\mathrm{kah}=$ bukukah, buku + pun $=$ bukupun .

b. Kata ganti kepunyaan (Possive Pronoun) -ku, -mu, -nya.

Contoh $:$ buku $+\mathrm{mu}=$ bukumu, buku $+\mathrm{ku}=$ bukuku, buku + nya $=$ bukunya.

c. $\quad$ Awalan (Prefix) ber-, per,-, me, di-, ter-, ke-, se-, dan pe-.

Contoh $:$ ber + main $=$ bermain, me + lempar $=$ melempar, $\mathrm{di}+$ makan $=$ dimakan, ter + ambil $=$ terambil, $\mathrm{ke}+$ pasar $=$ kepasar, se + banyak $=$ sebanyak, pe + malu $=$ pemalu.

d. Akhiran (Suffix) -kan, -an, -i, dan -nya.

Contoh $:$ dengar + kan $=$ dengarkan, akhir $+\mathrm{i}=$ akhiri, bentuk + nya $=$ bentuknya

e. $\quad$ Sisipan (Infix) -el-, -em, dan -er-.

Contoh : telunjuk, gemuruh, gerigi.

f. Imbuhan gabung (Confix) ber-kan, ber-an, per-kan, per-i, me-kan, me-i, memper-, memper-kan, memper-i, di-kan, di-i, diper-, diper-kan, diper-i.

Contoh : ber + dasar + kan $=$ berdasarkan, ber + datang + an $=$ berdatangan, per + satu + kan $=$ persatukan, memper + tanya + kan $=$ mempertanyakan.

\subsection{Stemming}

Stemming merupakan suatu proses yang terdapat dalam sistem IR (Information retrieval) yang mentransformasi kata-kata yang terdapat dalam suatu dokumen ke kata-kata akarnya (root word) dengan menggunakan aturan-aturan tertentu (Agusta, 2009). Stemming adalah proses pemetaan dan penguraian berbagai bentuk (variants) dari suatu kata menjadi bentuk kata dasarnya (stem). Proses stemming secara luas sudah digunakan di dalam Information retrieval (pencarian informasi) untuk meningkatkan kualitas informasi yang didapatkan. Kualitas informasi yang dimaksud misalnya untuk mendapatkan hubungan antara varian kata yang satu dengan yang lainnya. Sebagai contoh kata "diculik", "menculik" (melakukan tindakan menculik) dan "penculik" (orang yang menculik) yang semula mengandung arti yang berbeda dapat distem menjadi sebuah kata "culik" yang memiliki arti yang sama sehingga kata-kata diatas saling berhubungan. Selain itu stemming juga dapat digunakan untuk mengurangi ukuran dari suatu ukuran index file. Misalnya dalam suatu deskripsi terdapat varian kata "memberikan", "diberikan", "memberi" dan "diberi" hanya memiliki akar kata (stem) yaitu "beri". Proses stemming pada teks berBahasa Indonesia berbeda dengan stemming pada teks berbahasa Inggris. Pada teks berbahasa Inggris, proses yang diperlukan hanya proses menghilangkan sufiks (akhiran). Sedangkan pada teks berbahasa Indonesia, selain sufiks, prefiks, dan konfiks juga dihilangkan.

\subsection{Penelitian Terkait}

a. Penelitian yang dilakukan oleh Ledy Agusta (Agusta, 2009) dengan judul: "Perbandingan algoritma stemming Porter dengan algoritma Nazief dan Adriani Untuk stemming Dokumen Teks Bahasa Indonesia". Penelitian ini membandingkan efektifitas dari algoritma stemming Porter dengan Algoritma Nazief dan Adriani. Untuk membandingkan performa masing-masing algoritma stemming, dibuat program sederhana untuk memproses dokumen teks inputan sehingga diketahui hasil stem, waktu proses, presisi dari hasil stemming dokumen tersebut. Uji Coba algoritma dilakukan pada 30 dokumen teks Bahasa Indonesia dengan ukuran dokumen yang bervariasi. Hasil uji coba dokumen teks yang dilakukan menunjukkan bahwa :

- Proses stemming dokumen teks berBahasa Indonesia menggunakan Algoritma Porter membutuhkan waktu yang lebih singkat dibandingkan dengan stemming menggunakan Algoritma Nazief dan Adriani.

- Proses stemming dokumen teks berBahasa Indonesia menggunakan Algoritma Porter memiliki presentase keakuratan (presisi) lebih kecil dibandingkan dengan stemming menggunakan Algoritma Nazief dan Adriani.

b. Penelitian yang dilakukan oleh Mardi Siswo Utomo (Utomo, 2013) dengan judul: "Implementasi Stemmer Tala pada Aplikasi berbasis web". Pada penelitian ini dilakukan evaluasi pada 1000 kata terbanyak pada algoritma stemming Tala. Kata-kata tersebut telah bebas dari stopword/stopwords. Kesalahan karena overstemming paling banyak terjadi, dari 1000 kata terdapat 177 kata yang salah karena overstemming. Kemudian untuk bahasa asing tidak terjadi perubahan karena akhiran dan 
Jurnal Inkofar * Volume 1 No. 1, Juli 2017 * ISSN: 2615-3645 (Print) / 2581-2920 (Online)

Tersedia secara online di: http://www.politeknikmeta.ac.id/meta/ojs/

awalan tidak dikenali oleh sistem. Selanjutnya kesalahan juga terjadi pada nama orang/ istilah/singkatan.

Kebanyakan kata dengan akhiran 'i' akan terpotong oleh sistem huruf 'i' terakhirnya, karena tidak ada mekanisme pendeteksi apakah 'i' tersebut akhiran atau bagian dari kata. Kesalahan juga terjadi pada kesalahan ketik / masukan kata, susunan imbuhan yang salah atau imbuhan asing secara statistik, dari 1000 kata tersebut terdapat 256 kata yang mengalami kesalahan pencarian kata dasar, sehingga tingkat keberhasilannya adalah $74,4 \%$.

c. Penelitian yang dilakukan oleh Muhammad Latif Rozi (Rozi, 2013) dengan judul: "Implementasi dan Analisis Perbandingan Algoritma Stemming Nazief dan Adriani dengan Algoritma Stemming Vega dalam Information Retrieval System". Untuk mengetahui hasil dari algoritma stemming Nazief dan Adriani dan algoritma stemming Vega, maka dibuat information retrieval system yang dapat memperlihatkan performansi yang dihasilkan kedua algoritma tersebut. Pengujian dilakukan dengan menggunakan parameter waktu, akurasi, Word Conflation Class, dan Index Compression Factor.

Word Conflation Class adalah ukuran rata-rata kumpulan kata yang sudah melalui proses stemming, terlepas kata dasar hasil proses stemming benar atau salah. Index Compression Factor adalah seberapa besar jumlah kata-kata unik didalam dokumen dapat tereduksi dengan adanya proses stemming. Kemudian kedua algoritma stemming tersebut akan diterapkan di dalam Information Retrieval System. Berdasarkan pengujian yang dilakukan, maka diperoleh hasil sebagai berikut :

- Algoritma Nazief dan Adriani memiliki waktu proses yang lebih besar daripada algoritma Vega. Rata-rata waktu proses stemming pada Algoritma Nazief dan Adriani sebesar 2,87 detik sedangkan rata-rata waktu proses Algoritma Vega sebesar 0,04 detik.

- Algoritma Nazief dan Adriani memiliki akurasi yang lebih besar dari pada algoritma Vega. Rata-rata akurasi Algoritma Nazief dan Adriani sebesar 82,84\% sedangkan rata-rata akurasi Algoritma Vega sebesar 60,37\%.

- Algoritma Vega memiliki nilai WCC dan ICF yang relatif lebih besar daripada algoritma Nazief dan Adriani. Perbedaan nilai WCC dan ICF antara algoritma Nazief dan Adriani dengan algoritma Vega tidak terlalu besar. Rata-rata nilai WCC dan ICF Algoritma Nazief dan Adriani masing-masing sebesar 1,06 dan 0,057. Sedangkan nilai WCC dan ICF Algoritma Vega masing-masing sebesar 1,064 dan 0,06.

- Untuk query yang menjurus ke istilah dalam bidang tertentu, hasil Information Retrieval System antara algoritma Nazief dan Adriani dan algoritma Vega relatif sama.

\section{METODE PENELITIAN}

\subsection{Pengumpulan Data}

Data yang mendukung dalam penelitian ini diambil dari kamus besar bahasa Indonesia. Data juga diperoleh dengan membaca dan mempelajari referensi maupun dokumen yang berhubungan langsung dengan permasalahan dalam penelitian juga koleksi dokumen yang digunakan.

\subsection{Metode yang diusulkan}

Metode yang diusulkan untuk penelitian ini menggunakan pendekatan algoritma stemming berbasis kamus dan algoritma stemming menggunakan aturan imbuhan untuk dokumen teks Bahasa Indonesia.

\subsection{Tahap preprocessing}

Langkah preprocessing ini digunakan untuk menghilangkan bagian-bagian yang tidak diperlukan yang terdapat pada sebuah dokumen dimana hal ini akan menjadi noise pada proses selanjutnya, selain itu langkah preprocessing ini sendiri berfungsi sebagai parameter input algoritma stemming.

\subsection{Algoritma stemming}

Dalam penelitian ini akan digunakan algoritma stemming Nazief dan Adriani, algoritma Arifin dan Setiono, algoritma Vega dan algoritma Tala untuk mendapatkan kata dasar dalam bahasa Indonesia. Masing-masing algoritma stemming akan diujikan dengan dataset yang sama dan hasilnya akan dievaluasi. 
Jurnal Inkofar * Volume 1 No. 1, Juli 2017 * ISSN: 2615-3645 (Print) / 2581-2920 (Online)

Tersedia secara online di: http://www.politeknikmeta.ac.id/meta/ojs/

\subsection{Eksperimen dan pengujian dataset}

Untuk memudahkan dalam melakukan pengujian maka dilakukan testing model terhadap aplikasi stemming yang sudah dibuat sebelumnya. Selanjutnya akan dilakukan evaluasi terhadap hasil stemming. Evaluasi dilakukan untuk mengetahui waktu proses stemming nilai akurasi dari masing-masing algoritma dan juga kata-kata yang mengalami overstemming dan understemming. Adapun tahapan pengujian yang dilakukan dapat dilihat pada gambar 1 dan gambar 2.

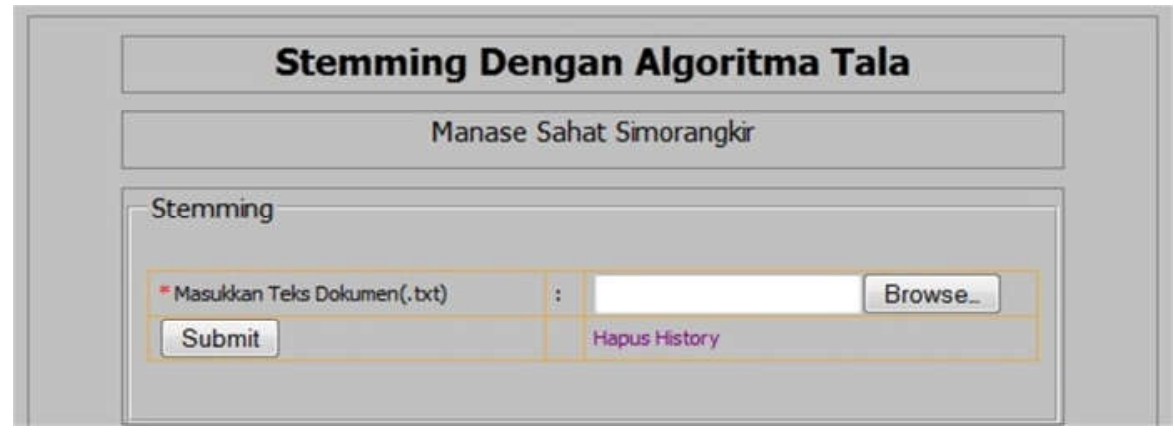

Gambar 1. Halaman input dokumen pengujian

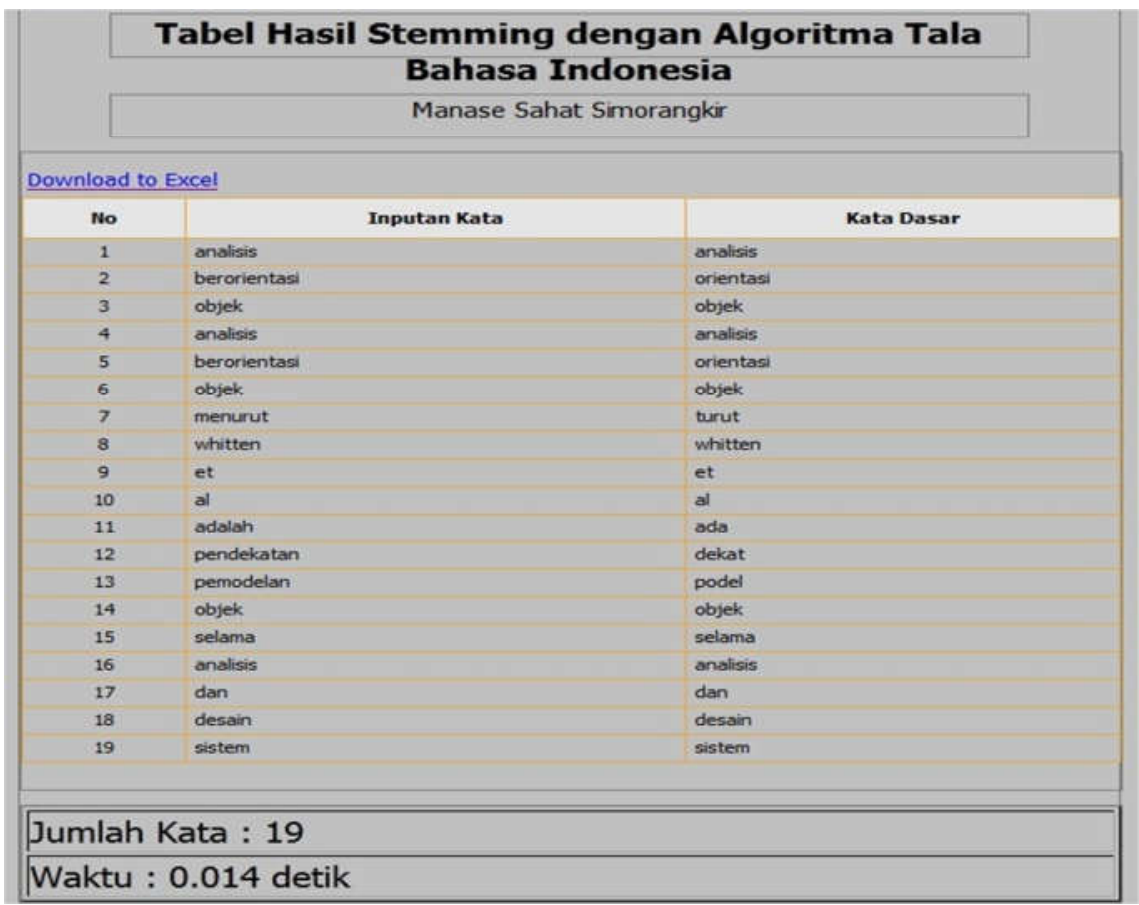

Gambar 2. Halaman output hasil pengujian

\section{HASIL DAN PEMBAHASAN}

\subsection{Koleksi Dokumen}

Koleksi dokumen yang digunakan untuk pengujian adalah dokumen sampel sebanyak 100 dokumen yang sudah dibuat dengan format berekstensi .txt. Kata-kata dalam dokumen tersebut diperoleh dari isi artikelartikel dan berita, baik artikel tentang kesehatan, artikel teknik, artikel keilmuan maupun berita-berita dari media elektronik. Total kata keseluruhan pada 100 dokumen adalah 25.937 kata.

\subsection{Kamus}

Pada penelitian ini, kamus kata dasar diambil dari daftar kata dasar pada Kamus Besar Bahasa Indonesia (KBBI) luring CHM V1.5 yang diunduh dari ebsoft.web.id. Total kata dasar dalam kamus adalah sebanyak 31.590 kata dasar. 
Jurnal Inkofar * Volume 1 No. 1, Juli 2017 * ISSN: 2615-3645 (Print) / 2581-2920 (Online)

Tersedia secara online di: http://www.politeknikmeta.ac.id/meta/ojs/

\subsection{Relevance judgments}

Pada penelitian ini, sebelum dilakukan evaluasi tentang performansi hasil stemming baik waktu proses, akurasi kata maupun kata-kata yang mengalami overstemming dan understemming dalam setiap dokumen maka dibuat relevance judgments per kata untuk melihat seberapa relevannya hasil stemming terhadap relevance judgments yang dibuat secara pengetahuan manusia. Relevance judgments yang dibuat adalah berupa kata dasar saja seperti pada Tabel 1.

Tabel 1. Relevance judgments pada dokumen hasil stemming

\begin{tabular}{|c|l|l|l|}
\hline No & Inputan Kata & Hasil Stemming & Relevance judgments (kata dasar) \\
\hline 1 & judul & judul & judul \\
\hline 2 & atmosfer & atmosfer & atmosfer \\
\hline 3 & bumi & bumi & bumi \\
\hline 4 & akurasi & akurasi & akurasi \\
\hline 5 & terperiksa & periksa & periksa \\
\hline 6 & melingkupi & lingkup & lingkup \\
\hline 7 & adalah & adalah & adalah \\
\hline 8 & lapisan & lapis & lapis \\
\hline
\end{tabular}

\subsection{Evaluasi Pengukuran}

Evaluasi pengukuran terhadap hasil proses stemming dilakukan secara detail mulai dari dokumen pertama sampai dokumen yang terakhir. Masing-masing algoritma stemming akan diuji menggunakan 100 dokumen. Adapun pengukuran yang dilakukan adalah sebagai berikut :

a. Waktu proses

Waktu proses hasil stemming akan ditampilkan dalam satuan detik.

b. Akurasi

$$
\text { Akurasi }=(\text { Kata dasar hasil stemming }=\text { Relevance judgments }) \times 100 \%
$$

$$
\text { Jumlah kata dalam dokumen }
$$

c. Overstemming adalah kata yang terlalu banyak dipotong setelah dilakukan proses stemming dibandingkan dengan jumlah kata dalam dokumen.

d. Understemming adalah kata yang terlalu sedikit dipotong setelah dilakukan proses stemming dibandingkan dengan jumlah kata dalam dokumen.

\subsection{Hasil Pengujian}

\section{a. Analisa Hasil pengujian}

Hasil pengujian 100 dokumen terhadap masing-masing algoritma stemming dapat dilihat pada Tabel 2 berikut ini:

Tabel 2. Hasil rata-rata pengujian algoritma stemming

\begin{tabular}{|c|c|c|c|c|}
\hline Algoritma & $\begin{array}{c}\text { Waktu Proses } \\
\text { (detik) }\end{array}$ & $\begin{array}{c}\text { Akurasi } \\
(\mathbf{\%})\end{array}$ & $\begin{array}{c}\text { Overstemming } \\
(\mathbf{\%})\end{array}$ & $\begin{array}{c}\text { Understemming } \\
(\mathbf{\% )}\end{array}$ \\
\hline Nazief \& Adriani & 5,147 & 97,931 & 1,400 & 0,397 \\
\hline Arifin \& Setiono & 15,204 & 92,099 & 6,102 & 1,561 \\
\hline Vega & 0,085 & 63,486 & 30,332 & 6,061 \\
\hline Tala & 0,22 & 78,274 & 19,085 & 1,706 \\
\hline
\end{tabular}

Dari tabel hasil pengujian diatas terlihat bahwa rata-rata waktu proses stemming yang paling singkat terdapat pada algoritma stemming Vega hal ini dikarenakan tidak ada pengecekan kata dasar terhadap kamus. Selanjutnya rata-rata nilai akurasi hasil stemming yang paling besar terdapat pada algoritma stemming Nazief dan Adriani, hal ini dikarenakan pada algoritma tersebut menggunakan kamus kata dasar dan algoritmanya memiliki aturan morfologi imbuhan yang diperbolehkan dan yang tidak diperbolehkan. Untuk Overstemming dan Undestemming yang paling kecil terdapat pada algoritma stemming Nazief dan Adriani. 
Jurnal Inkofar * Volume 1 No. 1, Juli 2017 * ISSN: 2615-3645 (Print) / 2581-2920 (Online)

Tersedia secara online di: http://www.politeknikmeta.ac.id/meta/ojs/

\section{b. Analisa kesalahan hasil stemming}

Evaluasi kesalahan hasil stemming pada setiap algoritma berbeda-beda, kesalahan terjadi karena masingmasing algoritma memiliki karakteristik yang berbeda ketika sebuah kata dilakukan proses stemming. Kesalahan tidak hanya terjadi pada kata dasar atau kata berimbuhan saja, tetapi kesalahan juga disebabkan karena salah pengetikan kata dalam dokumen yang digunakan. Selain itu kesalahan juga terjadi pada nama tempat, nama orang dan istilah juga bahasa asing baik pada algoritma yang menggunakan kamus maupun pada algoritma yang menggunakan aturan imbuhan. Berikut kesalahan hasil stemming karena pengetikan kata yang salah dalam dokumen.

Tabel 3. Kesalahan hasil stemming karena kesalahan pengetikan kata

\begin{tabular}{|l|l|l|l|}
\hline Contoh & Seharusnya & Hasil stemming & Kata dasar \\
\hline adaalah & adalah & adaalah & adalah \\
\hline bartahun & bertahun & bartahun & tahun \\
\hline diataati & ditaati & diataati & taat \\
\hline denganya & dengannya & denga & dengan \\
\hline dikembamngkan & dikembangkan & dikembamngkan & kembang \\
\hline tetang & tentang & tang & tentang \\
\hline kuargaku & keluargaku & kuarga & keluarga \\
\hline lagkah & langkah & lag & langkah \\
\hline tebuat & terbuat & tebuat & buat \\
\hline inginya & inginnya & ingi & ingin \\
\hline kemajuanm & kemajuan & kemajuanm & maju \\
\hline kemorosotan & kemerosotan & kemorosotan & merosot \\
\hline menganggab & menganggap & menganggab & anggap \\
\hline
\end{tabular}

Tabel 4. Kesalahan hasil stemming terhadap nama orang, tempat dan istilah

\begin{tabular}{|l|l|l|}
\hline Contoh & Hasil stemming & Seharusnya \\
\hline asian & asi & tetap \\
\hline bali & bal & tetap \\
\hline bekasi & bekas & tetap \\
\hline lan & l & tetap \\
\hline yadi & yad & tetap \\
\hline diego & ego & tetap \\
\hline abdullah & abdul & tetap \\
\hline bayi & bay & tetap \\
\hline bakri & bakr & tetap \\
\hline betawi & betaw & tetap \\
\hline bisri & bisr & tetap \\
\hline budhiman & budhim & tetap \\
\hline dahlan & dahl & tetap \\
\hline deputi & deput & tetap \\
\hline diet & et & tetap \\
\hline dki & dk & tetap \\
\hline edi & ed & tetap \\
\hline
\end{tabular}

Tabel 5. Kesalahan hasil stemming terhadap bahasa asing

\begin{tabular}{|l|l|l|}
\hline Contoh & Hasil stemming & Seharusnya \\
\hline fireman & firem & tetap \\
\hline members & s & tetap \\
\hline medicine & cine & tetap \\
\hline megaphone & gaphone & tetap \\
\hline
\end{tabular}


Jurnal Inkofar * Volume 1 No. 1, Juli 2017 * ISSN: 2615-3645 (Print) / 2581-2920 (Online)

Tersedia secara online di: http://www.politeknikmeta.ac.id/meta/ojs/

\section{KESIMPULAN DAN SARAN}

Berdasarkan hasil penelitian dan pembahasan yang disampaikan pada bab sebelumnya, maka terdapat beberapa kesimpulan sebagai berikut:

1. Untuk algoritma yang menggunakan kamus ditemukan algoritma terbaik dalam proses stemming yaitu algoritma Nazief dan Adriani. Hal ini dikarenakan pada algoritma Nazief dan Adriani terdapat penambahan aturan-aturan untuk reduplikasi, penambahan aturan untuk awalan dan akhiran dalam meningkatkan presisi dari setiap kata yang distemming.

2. Untuk algoritma yang menggunakan aturan imbuhan ditemukan algoritma terbaik dalam proses stemming terdapat pada algoritma Tala. Hal ini dikarenakan dalam algoritma Tala ada aturan cluster penggunaan imbuhan.

3. Kesalahan hasil stemming terhadap nama tempat, nama orang dan istilah maupun pengetikan kata yang salah dalam dokumen tidak terlalu mempengaruhi peningkatan akurasi. Mengingat jumlah kata yang salah karena hal tersebut tidak terlalu banyak dibanding dengan jumlah total kata keseluruhan.

Ada beberapa hal yang perlu disampaikan agar menjadi bahan pertimbangan untuk melengkapi penelitian dimasa mendatang. Hal-hal tersebut diungkapkan dalam bentuk saran sebagai berikut:

1. Pengujian dilakukan lagi pada jumlah kata yang lebih besar dalam sebuah dokumen seperti isi skripsi, tesis maupun disertasi yang berBahasa Indonesia.

2. Untuk mengurangi tingkat kesalahan perlu dilakukan modifikasi pada algoritma dengan menyempurnakan aturan pemenggalan imbuhan yang digunakan pada setiap algoritma, baik penggunaan partikel, awalan, akhiran maupun sisipan.

\section{UCAPAN TERIMAKASIH}

Penelitian yang dilakukan oleh penulis di Laboratorium Teknik Komputer Politeknik META Industri Cikarang ini didanai oleh Politeknik Meta Industri Cikarang, Oleh karena itu penulis mengucapkan terimakasih.

\section{DAFTAR PUSTAKA}

Agusta, L 2009. 'Perbandingan Algoritma Stemming Porter dengan Algoritma Nazief \& Adriani untuk Stemming Dokumen Teks Bahasa Indonesia'. Konferensi Nasional Sistem dan Informatika. KNS\&I09-036.

Arifin, A, Z \& Setiono, A, N 2002. 'Klasifikasi Dokumen Berita Kejadian Berbahasa Indonesia dengan Algoritma Single Pass Clustering'. Institut Teknologi Sepuluh November (ITS).

Surabaya.www.its.ac.id.

Chaer, A 2011. Tata Bahasa Praktis Bahasa Indonesia, Rineka Cipta Jakarta. Indonesia.

Kamus Besar Bahasa Indonesia (KBBI) luring CHM V1.5, ebsoft.web.id. diakses Rabu 25 November 2015.

Nazief, B \& Adriani, M 1996. 'Confix-Stripping: Approach to Stemming Algorithm for Bahasa Indonesia'. Fakulty of Computer Science. University of Indonesia.

Rozi, M, L 2013. 'Implementasi dan Analisis Perbandingan Algoritma Stemming Nazief dan Adriani dengan Algoritma Stemming Vega dalam Information Retrieval System'. Telkom University, Bandung.

Tala, F, Z 2004. 'A Study of Stemming Effects on Information Retrieval in Bahasa Indonesia', Institute for Logic, Language and Computation Universiteit van Amsterdam The Netherlands.

Utomo, M, S 2013. 'Implementasi stemmer Tala pada Aplikasi Berbasis Web', Jurnal Teknologi Informasi DINAMIK, Volume 18, No.1.

Vega, V, B 2001. 'Information Retrieval for the Indonesian Language'. Master"s thesis, National University Singapore. 